\section{ECONOMICS}

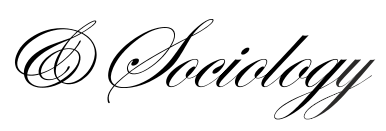

Wojciech Augustyniak

PhD

Department of Microeconomics

Poznan University of Economics

Poznan, Poland

E-mail:

w.angustyniak@ue.poznan.pl

Received: January, 2014

1st Revision: March, 2014

Accepted: April, 2014

DOI: $10.14254 / 2071-$

789X.2014/7-1/8
Wojciech Augustyniak, Efficiency Change in Regional Airports During Market Liberalization, Economics \& Sociology, Vol. 7, No 1, 2014, pp. 85-93. DOI: 10.14254/2071-789X.2014/7-1/8

\title{
EFFICIENCY CHANGE IN REGIONAL AIRPORTS DURING MARKET LIBERALIZATION
}

\begin{abstract}
The main purpose of this article is to measure the DEA efficiency scores of 4 Polish airports before and after market liberalization in comparison to the reference group that comprised 11 German airports in order to determine the impact of EU accession on their performance. In May 2004 Poland, Czech Republic, Slovakia and seven other countries joined the structures of the European. Since that date their airspaces has being covered by the Open Skies agreements which meant deregulation of their air transport markets. Results published in this article suggest that joining the EU had a positive impact on the financial efficiency of airports and had no impact on their technical efficiency.
\end{abstract}

JEL Classification: D24, C61

Keywords: airport efficiency, Data Envelopment Analysis, Poland, Germany.

\section{Introduction}

The most significant consequence of Poland becoming an EU member was the opening of the Polish air travel market to foreign competition in the form of low cost carriers. An increase in the share of LCCs in passenger air transport resulted in an increase in the scale of passenger transport and a reduction of unit revenue per one passenger transfer or per one air traffic operation. A comparison of the productivity and efficiency of Polish and German airports during two time periods, before and after EU accession, should reveal the impact of this change. It was assumed that all the remaining factors had the same impact on both markets.

In the group of Polish airports studied the ownership structure was unchanged - in both periods they were owned by state entities with $100 \%$ share. In the case of the German airports the ownership was private, state or mixed. The analysis included 4 Polish airports (GDN, KTW, POZ, WRO), 11 German airports (BRE, CGN, DRS, DTM, DUS, HAJ, HAM, LEJ, MUC, NUE, STR). The data from 2 Czech (BRQ, OSR) and 2 Slovak airports (BTS, KSC) were used to increase the sample size for DEA analysis in order to reduce the risk of "curse of dimensionality" (Adler and Yazhemsky, 2010). All the data include ground handling activities.

The main objective of this paper is to examine the impact of Poland's entry into the European Union on the efficiency of Polish airports. The analysis of efficiency was divided 
into two parts: financial with mainly financial variables and technical with technical variables. It is essential to compare the technical and financial efficiency of Polish and German airports in the division of time series for the periods 2000-2004 and 2005-2010 therefore the DEA efficiency results obtained in both analysis were split into groups: before and after liberalization of Polish aviation market. The year 2004 was chosen as the frontier date, as in May 2004 Open Skies Agreement was launched between Poland and other EU members. The U Mann Whitney test was chosen to examine the hypothesis about the change in efficiency after liberalization.

The paper consist of 4 parts:

- introduction: where the main objectives are stated,

- methodology: where the theoretical background for the used methods is provided,

- literature review: giving references related to analyzed topic,

- empirical results: describing each stage of calculation and obtained results,

- conclusion: containing discussion, limitation and further research.

\section{Methodology}

In order to verify the relationships presented above, the same data were analysed again by means of a different methods. The method used to assess the efficiency of Polish and German airports was Data Envelopment Analysis (DEA), a method widely used in this area of research. This comparison between indicator analysis and synthetic measures was inspired by publications from, among others, Graham and Holvad (2000), Oum et al. (2003), Oum et al. (2004) and Vogel (2004).

The DEA method is based on the concept of productivity devised by Farrel (1957); defined as the quotient of the weighted sum of outputs to the weighted sum of inputs (Charnes et al., 1978). DEA is a technique of linear programming for measuring the relative efficiency of decision making units (DMUs). The DEA method can be used for researching units with many input and output variables representing, respectively, inputs and outputs. This is also possible even if the values of the variables are expressed in different units (e.g. passengers in numbers and freight in tonnes). During the analysis the examined items are compared to a homogenous group of similar objects, from which so called benchmarks are set. These are entities of relative efficiency equal to $100 \%$. In contrast to ratio models (e.g. PFP), the weightings of the variables are automatically matched by the DEA model in such a way that the examined observation receives the highest possible result of efficiency in comparison to the other observations. The variable returns to scale input-oriented model involves the following primal of the linear programming problem:

$$
\min _{\theta, \lambda, s^{+}, s^{-}} z_{0}=\theta-\varepsilon \cdot \overrightarrow{\mathbf{1}} s^{+}-\varepsilon \cdot \overrightarrow{\mathbf{1}}^{-}
$$

Subject to:

$$
\begin{aligned}
& Y \lambda-s^{+}=Y_{0} \\
& \theta X_{0}-X \lambda-s^{-}=0 \\
& \overrightarrow{\mathbf{1}} \lambda=1 \\
& \lambda, s^{+}, s^{-} \geqslant 0
\end{aligned}
$$

where $X$ is the vector of the inputs used by the DMUs; $Y$ is the vector of the quantities produced by the DMUs; $\varepsilon$ is the infinitesimal non-Archimedean constant, which ensures that no weight is 
equal to zero; $s^{+}$and $s^{-}$are the slack vectors of the outputs and inputs, re-spectively; $h$ is the scalar variable that represents the possible radial reduction to be applied to all inputs so as to obtain the projected input values; 1 -hat is a unit vector; $k$ is the vector whose optimal values form a combination of units that make up the performance of the DMU under analysis, and establish a direction in which to identify the sources of inefficiency in this DMU.

The observations of the highest levels of efficiency create an isoquant which joins points of efficiency equal to $100 \%$. The level of inefficiency of the other observations is measured as their distance from the isoquant. An example is presented in Figure 1, where the DEA frontier is represented by the $\mathrm{ABCD}$ isoquant. Observations $\mathrm{A}, \mathrm{B}, \mathrm{C}$ and $\mathrm{D}$ are characterised by local efficiency equal $100 \%$. The observations which are situated below the envelope received a VRS score below $100 \%$. A measure of the local efficiency of observation $\mathrm{E}$ is the value of the quotient for the lengths of PA to PE segments.

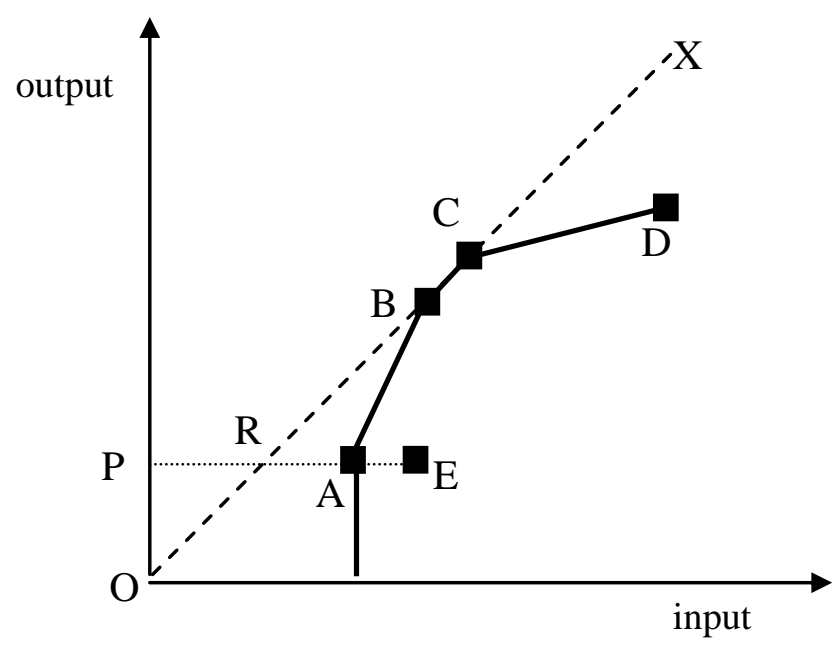

Figure 1. DEA frontier - input-oriented model

Source: Own compilation based on Cooper et al. (2000).

Applying the DEA method alone with a relatively large number of variables in relation to a small set of observations can lead to the so called "curse of dimensionality"; that is, a situation in which a lot of observations (DMUs) can achieve the result DEA $=100 \%$ for no reason. In such cases the examined observations are each efficient in their own way and are not usually benchmarks for further DMUs. In such a situation it is difficult to decide which features are the most favourable and which are the least for particular companies.

In order to avoid "the curse of dimensionality" a combination of Data Envelopment Analysis and Principal Component Analysis (PCA-DEA) was used according to the methodology proposed by Adler and Yazhemsky (2010). PCA-DEA analysis consists in changing DEA variables into principal component groups that are uncorrelated with each other and which describe approximately $80-90 \%$ of data variability. If the first few components represent the overwhelming majority of data variability, the original input and output variables can be replaced with these components and you can reject the remaining components without a substantial loss of information. In this way the dimensionality of DEA analysis is reduced, which increases its discriminatory value.

The U Mann-Whitney test is a nonparametric test for comparing two populations with their ranks. It is used to test the null hypothesis that two populations have identical distribution functions against the alternative hypothesis that the two distribution functions differ only with respect to median. It doesn't require the assumption that the differences 
between the two samples are normally distributed. It can be used in place of the two sample ttest when the normality assumption is questionable.

\section{Literature review}

Despite the impact of air transport market liberalisation on airline efficiency is widely covered - e.g. Fethi et al. (2001), Bruning (1991) - there is a relative scarcity of publications relating to research into the influence of liberalisation on the efficiency of airports. The most recent articles on airports efficiency are among others the following papers.

Lin and Hong (2006) used 8 variables as inputs: the number of employees, number of check-in desks, number of runways, number of parking spaces, number of baggage belts, number of gates, aprons and surface area of the terminal. As outputs they have chosen: the number of passengers (PAX), the number of flight operations (ATM) and the amount transferred tons of cargo. Calculation includes data from 20 major world airports. DEA results were subjected to statistical testing in order to identify factors with high impact on efficiency. The effect of ownership structure turned out to be irrelevant for efficiency. It was found that statistically significant determinants were: the location and level of economic development of the region and the status of a hub airport (hub).

Barros and Sampaio (2004) carry out the DEA calculation of 10 Portuguese airports in the years 1990-2000. Capital and labor cost were chosen as inputs. Revenues, number of aircraft movements, passengers and cargo were chosen as outputs. In the second stage of the analysis, the Tobit model was used to examine the impact of the following variables on efficiency: market share, the share of regional authorities, the location, the population of the region, cost structure. It was found that management style has a significant impact on the efficiency and the size of airport does not play a significant role.

Vogel (2004) analyzed 31 European airports for the period 1990-1999. Airports are divided into groups according to the type of property: fully private, partially privatized and fully state-owned. In addition to the DEA the author calculated partial and total productivity ratios, then provided statistical tests. As a result, it was found that, on average, private ports are the most efficient. It was also noted that fully privatized ports, despite obtaining higher operational efficiency, generate lower dividend to its shareholders than the partially privatized counterparts.

Müller, Ülkü and Živanović (2009) analyzed 6 German and 7 British airports for the period 1998-2005 using among others Partial Factor Productivity analysis and DEA to examine the impact of privatization on efficiency. The surface of the terminal, the number of check-in desks and the number of gates were chosen as inputs. As the only output variable they have used the number of passengers. The paper presents an unusual assumption that airports are focused on maximizing the effects with a constant level of inputs. Analysis of the results with Tobit model defended the hypothesis of the higher efficiency of the fully privatized entities as well as airports with very high passenger volume. The worst outcome in the study received entities with partial participation of private capital.

\section{Empirical research}

According to the practice which is most often used in the literature when applying the DEA method, it has been assumed that airports do not have much influence on the effects generated by airport activity because the volume of demand is dependent to the greatest degree on the enterprise of the carriers. A commonly applied assumption is made that the role of an airport is to provide infrastructure adequate for demand at the lowest possible cost. In this situation it is only possible to increase efficiency by minimizing expenditure for a given level of effects. This study therefore uses Data Envelopment Analysis input-oriented models. 
Calculations were carried out assuming variable (VRS) returns to scale. Table 1 presents a list of variables used in the DEA analysis.

Table 1. Variables used in the DEA analysis

\begin{tabular}{ccc}
\hline & Financial efficiency & \\
\hline Inputs & Outputs \\
\hline Staff cost (TLC) & Total revenue (TR) \\
\hline Capital cost (CC) & Passengers (PAX) \\
\hline & Technical efficiency & \\
\hline Inputs & Outputs \\
\hline Employees (emp) & Air transport movements (ATM) \\
\hline Terminal area [m $\left.{ }^{2}\right]$ (TA) & Cargo with mail[t] (carg) \\
\hline Number of gates (gate) & Passengers(PAX) \\
\hline Number of check-in counters (check) & \\
\hline
\end{tabular}

Source: own compilation.

The selection of variables for the financial analysis was based on publications by Barros and Sampaio (2004) and Martin and Roman (2001), who used capital cost and labour cost as inputs, and information about revenues and volume of traffic as outputs. As regards technical data, their choice was based on the analysis conducted by Lin and Hong (2006), excluding the number of runways, parking spaces and baggage belts. This was due in part to lack of data, but not only. It can be observed that a decreasing share of passengers travel with dedicated baggage at regional airports, in which a lot of flights are operated by low-cost carriers. What is more, baggage claim belts differ in terms of design and capacity, therefore their number only reflects the differences in terminal capacity to a small degree. This means that fewer and fewer passengers need belts to transfer through an airport. The length and number of runways were not analysed as most regional airports use only one runway, the length of which is usually close to $2.5 \mathrm{~km}$. In the analyses that follow, in order to avoid the "curse of dimensionality" PCA at the level of 99\% was used.

Table 2. Comparison of descriptive statistics before and after market liberalization

\begin{tabular}{lrrrrrrr}
\hline & Mean & Median & St. dev. & Mean & Median & St. dev. \\
\hline \multicolumn{7}{c}{ Financial efficiency } & \multicolumn{5}{c}{ Technical efficiency } \\
\hline \multicolumn{7}{c}{ Before liberalization } \\
\hline POZ & $78,56 \%$ & $77,92 \%$ & $18,13 \%$ & POZ & $48,93 \%$ & $35,55 \%$ & $28,57 \%$ \\
\hline GDN & $69,50 \%$ & $63,23 \%$ & $11,41 \%$ & GDN & $47,56 \%$ & $47,33 \%$ & $1,02 \%$ \\
\hline KTW & $58,02 \%$ & $59,59 \%$ & $9,36 \%$ & KTW & $65,33 \%$ & $65,21 \%$ & $3,09 \%$ \\
\hline WRO & $66,48 \%$ & $66,21 \%$ & $2,38 \%$ & WRO & $44,48 \%$ & $44,14 \%$ & $0,95 \%$ \\
\hline \multicolumn{7}{c}{ After liberalization } \\
\hline POZ & $79,87 \%$ & $81,25 \%$ & $7,62 \%$ & POZ & $41,38 \%$ & $41,83 \%$ & $5,50 \%$ \\
\hline GDN & $94,31 \%$ & $95,44 \%$ & $6,28 \%$ & GDN & $71,91 \%$ & $73,27 \%$ & $10,84 \%$ \\
\hline KTW & $82,02 \%$ & $81,96 \%$ & $6,37 \%$ & KTW & $51,11 \%$ & $45,66 \%$ & $14,54 \%$ \\
\hline WRO & $80,90 \%$ & $83,07 \%$ & $13,58 \%$ & WRO & $64,23 \%$ & $63,39 \%$ & $11,89 \%$ \\
\hline
\end{tabular}

Source: own calculations.

In order to test whether accession to the EU had an impact on the financial efficiency of airports PCA-DEA financial results were compared for the periods 2000-2004 and 20052010. Table 2 presents descriptive statistics in four Polish regional airports before and after 
market liberalization. 3 out of 4 airports have improved average financial efficiency and one airport reported worse average values. In case of technical efficiency 2 airports have improved average efficiency values and other two have worsen. Table 3 presents the results of a Mann-Whitney $U$ test for differences in the levels of financial efficiency. The operators of German airports on average displayed a slightly higher financial efficiency than Polish operators, though the change became statistically significant only at a significance level of $\alpha=0.1(p=0.0665)$.

Table 3. Comparison of financial efficiency (PCA-DEA method) - Mann-Whitney U test

\begin{tabular}{ccccccccc}
\hline Market & $\begin{array}{c}\text { Sum of } \\
\text { ranks 2005- } \\
2010\end{array}$ & $\begin{array}{c}\text { Sum of } \\
\text { ranks 2000- } \\
2004\end{array}$ & U & Z & p & $\begin{array}{c}\text { N of obs. } \\
2005-2010\end{array}$ & $\begin{array}{c}\text { N of obs. } \\
\text { 2000-2004 }\end{array}$ \\
\hline Poland & 698.0 & 292.0 & 82.0 & 3.712311 & 0.000205 & 24 & 20 \\
\hline Germany & 4318.5 & 3062.5 & 1522.5 & 1.519988 & 0.128515 & 66 & 55 \\
\hline
\end{tabular}

Source: own calculations.

The findings support the hypothesis which assumed the favourable impact of Poland's entry into the EU on financial efficiency. The Mann-Whitney $U$ test revealed that in a deregulated aviation market Polish airports achieved significantly higher results than before joining the EU. At the same time in the case of German airports, there were no statistically significant differences in terms of financial efficiency between the periods 2000-2004 and 2005-2010. A significant increase in the efficiency of Polish airports after 2004 and an absence of such a phenomenon in the reference group (German airports) proves that Poland's entry into the EU and implementing the Open Skies common aviation market had a positive impact on the financial efficiency of Polish airports.

The sources of those increases can be indirectly attributed to increased passenger traffic, caused by low-cost carriers utilising the market potential and the ground infrastructure potential which could not be fully exploited before the implementation of Open Skies agreements. The immediate cause of the improvement in the financial efficiency of airports was a significant increase in the revenues of regional airports, which in many cases only after Poland's entry into the EU allowed them to cross the profitability threshold.

To test whether joining the EU had an impact on the technical efficiency of airports DEA technical results were compared for the periods 2000-2004 and 2005-2010. Table 4 presents the results of a Mann-Whitney $U$ test for the differences in the levels of technical efficiency. Just as in the case of financial productivity, the operators of German airports recorded a significantly higher technical efficiency than their Polish counterparts $(\mathrm{p}=0.00002)$.

Table 4. Comparison of technical efficiency (DEA method)) - Mann-Whitney U test

\begin{tabular}{|c|c|c|c|c|c|c|c|}
\hline Market & $\begin{array}{c}\text { Sum of } \\
\text { ranks } 2005- \\
2010\end{array}$ & $\begin{array}{l}\text { Sum of } \\
\text { ranks } 2000- \\
2004\end{array}$ & U & $\mathrm{Z}$ & $\mathrm{p}$ & $\begin{array}{c}\text { N of obs. } \\
2005-2010\end{array}$ & $\begin{array}{c}\text { N of obs. } \\
2000-2004\end{array}$ \\
\hline Poland & 532.0000 & 414.0 & 224.0 & 0.08559 & 0.93178 & 24 & 19 \\
\hline Germany & 2412.000 & 2638.0 & 1153.0 & 0.61206 & 0.54049 & 46 & 54 \\
\hline
\end{tabular}

Source: own calculations. 
Despite an increase in the average level of technical efficiency of Polish airports after 2004, this change was not statistically significant. In the mature German market during the same periods a slight deterioration was observed in the average level of technical efficiency. The lack of statistically significant data means that the hypothesis relating to an improvement in the technical efficiency of airports after accession to the EU cannot be confirmed. Nevertheless, the trends in the changes of the average levels of technical DEA suggest that joining the European structures did not adversely affect the technical efficiency of Polish airports.

The lack of significance for the above correlations may be the consequence of numerous infrastructure development projects which aimed at improving the capacity and standards of Polish airports after 2004. It is worth noting that the vast majority of these projects were co-funded by the EU. In some cases the new infrastructure more than doubled an airport's capacity (for example KTW in 2007). The capacity of airports increased exponentially, sometimes outpacing the growth in air traffic. As a result of under-utilising the potential of the new infrastructure, the technical DEA results often deteriorated temporarily.

In the mature German market the capacity of airports increased less rapidly than it did in Poland. However, after 2007 both markets experienced stagnation in the development of air transport which affected the European market as a result of the global economic slowdown. One can assume that both those phenomena contributed to the lack of statistical significance for the changes presented in Table 4.

\section{Conclusions}

In 2004 Poland and nine other Central and Eastern European countries joined the European Union. Accession into the EU meant that these countries were included in EU directives relating to air transport as well as the Open Skies agreements. As a result of deregulating the market there was a dynamic growth of air traffic in Poland, which most strongly affected regional airports. What probably significantly contributed to those changes was Poland joining the Schengen Area as well as a gradual opening of their job markets by the EU-15. Previously, these airports operated in a hub-and-spoke system, mainly providing connections to the central airport in Warsaw. The Open Skies agreements made it possible for foreign low-cost carriers to enter the Polish market and to adopt a point-to-point model of flight routes.

A statistically significant increase of DEA scores of Polish airports after 2004, in the absence of similar increases in the majority of financial indicators of German airports, supports the hypothesis that joining the EU had a positive impact on the financial efficiency of airports. The technical relationship, however, was not confirmed in a statistically significant way by an analysis of the results of technical DEA. Last but not least, it was confirmed that German airports are on average more efficient than their Polish counterparts in both technical and financial terms in a statistically significant way.

These results are however subjected to limitation of the method which are nonparametric character of DEA that hampers further statistical hypothesis tests and relativity of scores that cannot provide information about theoretical maximum of efficiency. The other limitation of this study is lack of decompositions the technical efficiency scores with Malmquist index into efficiency change and frontier change regarded as technical and organisational evolution. Therefore for future research I recommend the use of Malmquist DEA to decompose technical results, bootstraping or second stage regression to improve the objectivity of results and provide further hypothesis testing. 


\section{References}

Adler N., Yazhemsky E. (2009), Improving discrimination in Data Envelopment Analysis: PCA-DEA versus Variable Reduction. Which method at what cost? European Journal of Operational Research, 01/2010, 202(1).

Alford E., Champley R. (2007), The impact of the 2007 U.S.-EU Open Skies Air Transport Agreement, ITA Occasional Paper no. 07-001.

Augustyniak W., Kalinowski S. (2011), Benchmarking oraz metody mierzenia efektywności portów lotniczych [Benchmarking and the methods for measuring airport efficiency], in: Rekowski M. (ed.), Regionalne porty lotnicze w Polsce - charakterystyka i tendencje rozwojowe, Wydawnictwo Uniwersytetu Ekonomicznego w Poznaniu, Poznań, pp. 239-255.

Barros, C.P., Sampaio, A. (2004), Technical and Allocative Efficiency in Airports, International Journal of Transport Economics, 31, pp. 355-377.

Brattle Group (2002), The impact of an EU-US Open Aviation Area, London and Washington.

Bruning, E. R. (1991), Market liberalization and operating efficiency in the international aviation industry, International Journal of Transport Economics, 18(3), pp. 259-274.

Charnes A., Cooper, W. W., Rhodes E. (1978), Measuring the efficiency of decision making units, European Journal of Operational Research 2, pp. 429-444.

Cooper W. W., Seiford L. M., Tone K. (2000), Data Envelopment Analysis: A Comprehensive Text with Models, Applications, References and DEA-Solver Software, Kluwer Academic Publisher, s. 12-150.

Doganis, R. (1992), The Airport Business, Routledge, London and New York.

ELFAA (European Low Fares Airline Association) (2009), Liberalization of European Air Transport: the Benefitsof Low Fares Airlines to Consumers, Airports, Regions and the Environment, Brussels.

Farrell M.J. (1957), The measurement of productive efficiency, J.R. Statis. Soc. Series A 120, pp. 253-261.

Fernandes E., R. R. Pacheco (2002), Efficient use of airport capacity, Transportation Research Part A, Volume 36, Number 3, pp. 225-238.

Fethi, M. D., Jackson, P. M., \& Weyman-Jones, T. G. (2001), European airlines: a stochastic dea study of efficiency with market liberalisation, https://dspace.lboro.ac.uk/2134/420

Forsyth P., King J., Rodolfo C. (2006), Open Skies in ASEAN, Journal of Air Transport Management 12, pp. 143-152.

Francis G., Fidato A., Humphreys I. (2003), Airport-airline interaction: the impact of lowcost carriers on two European airports, Journal of Air Transport Management 9, pp. 267-273.

Franke M. (2004), Competition between network carriers and low-cost carriers - retreat battle or breakthrough to a new level of efficiency?, Journal of Air Transport Management 10, pp. 15-21.

Gillen D., Lall A. (2004), Competitive advantage of low-cost carriers: some implications for airports, Journal of Air Transport Management 10, pp. 41-50.

Graham, A., Holvad, T. (2000), Efficiency Measurement for Airports, TrafikDags PAA Aalborg Universitet 2000 Conference, Aalborg University.

Lin, L.C., Hong, C.H. (2006), Operational performance evaluation of international major airports: An application of data envelopment analysis, Journal of Air Transport Management 12, pp. 342-351. 
Martin J.C., Roman C. (2001), An application of DEA to measure the efficiency of 79 Spanish airports prior to privatization, Journal of Air Transport Management, 7, pp. 149-157.

Müller, J., Ülkü, T., Živanović, J. (2009), Privatization, restructuring and its effects on performance: A comparison between German and British airports, Paper No. 2, Date: 04/2009, German Airport Performance, www.gap-projekt.de.

Oum, T.H., Yu, C. Fu, X. (2003), A comparative analysis of productivity performance of the world's major airports: summary report of the ATRS global airport benchmarking research report - 2002, Journal of Air Transport Management, 9(5), pp. 285-297.

Oum, T.H., Zhang, A. Zhang, Y. (2004), Alternative forms of economic regulation and their efficiency implications for airports, Journal of Transport Economics and Policy, 38(2), pp. 217-246.

Pavlyuk D. (2009), Spatial competition pressure as a factor of European airports' efficiency, Transport and Telecommunication, Volume 10, No 4, pp. 8-17.

Ray, S.C. (2004), Data Envelopment Analysis, Cambridge University Press, Cambridge.

Tae Hoon O., Chunyan Y., Xiaowen F. (2003), A comparative analysis of productivity performance of the world's major airports: summary report of the ATRS global airport benchmarking research report - 2002, Journal of Air Transport Management 9, pp. 285-297.

Vogel, H.-A. (2004), Airport Privatisation and Performance, PhD thesis, University of Westminster, School of Architecture and the Built Environment. 